Joyful Learning Journal

\title{
HUBUNGAN MOTIVASI DAN DISIPLIN BELAJAR TERHADAP HASIL BELAJAR MUPEL PJOK
}

\section{Zahrotun Nasihah $^{\bowtie}$, Isa Ansori}

Jurusan Pendidikan Guru Sekolah Dasar, Fakultas Ilmu Pendidikan, Universitas Negeri Semarang, Indonesia

\begin{tabular}{l} 
Info Artikel \\
\hline Sejarah Artikel: \\
Diterima Januari \\
$\mathbf{2 0 2 0}$ \\
Disetujui Februari \\
$\mathbf{2 0 2 0}$ \\
Dipublikasikan Maret \\
$\mathbf{2 0 2 0}$ \\
\end{tabular}

Keywords:

Discipline; Learning

Motivation; Outcomes of sport and physical learning

\begin{abstract}
Abstrak
Tujuan penelitian ini adalah menguji adanya hubungan yang positif dan signifikan antara motivasi dan disiplin belajar dengan hasil belajar Mupel PJOK pada siswa kelas V SDN Gugus Larasati Kecamatan Gunungpati Semarang. Penelitian ini adalah penelitian kuantitatif jenis korelasi. Pengambilan sampel dilakukan dengan teknik sampel jenuh sejumlah 119 siswa. Teknik pengumpulan data menggunakan angket, observasi, wawancara dan dokumentasi. Uji instrumen dilakukan dengan uji validitas dan uji reliabilitas. Teknik analisis data yang digunakan adalah analisis statistic deskriptif dan analisis product moment. Hasil analisis data dalam penelitian ini menunjukkan adanya hubungan yang positif dan signifikan antara motivasi dan disiplin belajar mupel PJOK, nilai $\mathrm{r}_{\text {hitung }}=0,743$ dan termasuk kategori kuat serta berkontribusi sebesar 55,1\%. Simpulan dari penelitian ini yaitu adanya hubungan yang positif dan signifikan antara motivasi dan disiplin belajar dengan hasil belajar Mupel PJOK siswa kelas V SDN Gugus Larasati Kecamatan Gunungpati Semarang.
\end{abstract}

\section{Abstract}

The purpose of this study was to examine the existence of a positive and significant correlation between motivation and learning discipline towards outcomes of sport and physical learning to the fifth grade students of the Larasati Elementary School Cluster, Gunungpati, Semarang. This research was a quantitative approach. The sampling technique used saturated sampling of 119 students. The data collection techniques were questionnaires, observation, interviews, and documentation. The instrument test used validity and reliability test. The data analysis techniques used were descriptive statistical analysis and product moment correlation analysis. The results of data analysis in this study showed that there was a positive and significant correlations between motivation and learning discipline and sport science learning outcomes, Rcount $=0.743$, and included in a strong category and contributes $55,1 \%$. The conclusion of this study there was a positive and significant correlation between motivation and learning discipline towards outcomes of sport and physical learning at fifth grade students of the Larasati Elementary School Cluster, Gunungpati, Semarang.

(C) 2020 Universitas Negeri Semarang

\footnotetext{
Alamat korespondensi:

RT 05 RW 01 Kerso, Kedung, Jepara

E-mail: xahro.harto@gmail.com
} 


\section{PENDAHULUAN}

Pendidikan merupakan hal penting bagi manusia. Melalui proses pendidikan seseorang mendapatkan kesempatan untuk mengembangkan berbagai potensi pada dirinya. Potensi tersebut dapat berkembang dengan baik apabila proses pendidikan yang dilalui memiliki mutu yang berkualitas. Pendidikan yang berkualitas berperan dalam menciptakan dan mengembangkan manusia yang bermutu baik. Terciptanya warga negara yang bermutu baik merupakan salah satu upaya dalam mewujudkan cita-cita bangsa Indonesia agar terwujud. Pendidikan jasmani atau biasa dikenal dengan PJOK merupakan bentuk pendidikan yang menggunakan aktivitas gerak sebagai media. Sepanjang usia pertumbuhan dan perkembangannya, seorang siswa akan mengalami tahap-tahap perkembangan tertentu. Tahap-tahap perkembangan tersebut memiliki karakteristik yang berbeda-beda. Perbedaan tersebut secara langsung memberikan implikasi yang berbeda terhadap rancang bangun program pembelajaran yang akan disusun (Victor 2008: 62).

Salah satu sikap yang sangat dibutuhkan ketika mengikuti kegiatan pembelajaran pendidikan jasmani adalah sikap disiplin. Sebab dengan sikap disiplin kegiatan pembelajaran pendidikan jasmani diharapkan akan lebih kondusif. Slameto (2013:67) mengatakan agar siswa lebih maju, siswa harus disiplin didalam belajar baik disekolah, dirumah maupun diperpustakaan.

Disiplin belajar dipandang sebagai faktor yang yang mempengaruhi prestasi belajar siswa. Sikap dan perilaku disiplin tidak terbentuk dengan sendirinya dan dalam waktu yang singkat, namun melalui proses yang cukup panjang. Disiplin akan terwujud melalui pembinaan yang dilakukan sejak dini mulai dari lingkungan keluarga dan berlanjut dalam pendidikan di sekolah. Keluarga dan sekolah menjadi tempat penting bagi perkembangan disiplin belajar siswa.

Selain sikap disiplin, motivasi belajar juga diperlukan dalam proses pembelajaran. Motivasi menurut Uno (2016:01) adalah dorongan dasar yang menggerakkan seseorang untuk bertingkah laku. Dorongan ini berada pada diri seseorang yang menggerakkan untuk melakukan sesuatu yang sesuai dengan dorongan dalam dirinya. Oleh karena itu, perbuatan seseorang didasarkan atas motivasi tertentu mengandung tema yang sesuai dengan motivasi yang mendasarinya. Keberhasilan dalam suatu pembelajaran dapat diketahui dengan adanya penilaian terhadap hasil belajar. Menurut Slameto (2013:32) belajar adalah suatu proses usaha yang dilakukan seseorang untuk memperoleh suatu perubahan tingkah laku yang baru secara keseluruhan, sebagai hasil pengalamannya sendiri dalam interaksi dengan lingkungannya. Perubahan tersebut tidak hanya pada aspek pengetahuan atau kognitif saja tetapi juga meliputi aspek sikap dan nilai (afektif) serta keterampilan (psikomotorik).

Berdasarkan hasil observasi yang dilakukan peneliti diperoleh hasil belajar siswa di gugus larasati pada mata pelajaran PJOK sebagian besar siswa memiliki nilai dibawah Kriteria Ketuntasan Minimal (KKM). Hal tersebut terbukti dari data hasil belajar Ulangan Harian siswa pada muatan pelajaran PJOK diperoleh 94 siswa (78\%) nilainya tuntas dan 25 siswa (22\%) nilainya belum tuntas. Hal ini dipengaruhi oleh motivasi dan disiplin siswa yang masih rendah, hal ini ditandai dengan terdapat siswa yang tidak mengumpulkan tugas tepat waktu, minat baca yang masih kurang, motivasi dan kesadaran untuk belajar siswa yang dinilai guru masih rendah, disiplin dalam belajar belum menjadi kebiasaan pada diri siswa, serta kurangnya fasilitas dan alat pembelajaran PJOK yang dimiliki sekolah.Beberapa penelitian terdahulu yang menginspirasi peneliti untuk melakukan penelitian ini adalah penelitian yang dilakukan Khalida Rozana Ulfah, Anang Santoso, Sugeng Utaya (2016) yang berjudul "Hubungan Motivasi Dan Hasil Belajar IPS". Hasil penelitian menunjukan bahwa sebagian besar siswa memiliki motivasi hasil belajar tinggi sehingga dapat disimpulkan terdapat hubungan motivasi dengan hasil belajar.

Selain itu penelitian yang dilakukan oleh Carlos Kambuaya tahun 2015 yang berjudul "Pengaruh Motivasi, Minat, Kedisiplinan Dan Adaptasi Diri Terhadap Prestasi Belajar Siswa Peserta Program Afirmasi Pendidikan Menengah Papua Dan Papua Barat Di Kota Bandung." Hasil penelitian menunjukan ada pengaruh sigmiikan antara motivasi terhadap prestasi belajar siswa yang ditunjukkan dan uji parsial yang diperoleh probabilitas 0,003 oos atau nilai $t$ hitung $(3,201) \mathrm{t}$ tabel $(1,983)$. Selanjutnya penelitian yang dilakukan oleh Ehiane, O. Stanley (2014) dalam International Journal of Academic Research in Progressive Education and Development (Vol. 3 No.1, ISSN: 22266348) dengan judul "Discipline and Academic Performance (A Study of Selected secondary Schools in Lagos, Nigeria)". Hasil kajian jelas menunjukkan keefektifan sekolah dalam disiplin seharusnya terus didorong dalam mengontrol siswa serta perilaku dengan demikian dapat mempengaruhi siswa dan pada umumnya prestasi akademik.

Tujuan dilaksanakan penelitian ini adalah: (1) menguji ada tidaknya hubungan yang positif dan signifikan antara motivasi dengan hasil belajar PJOK kelas V SD Negeri Gugus Larasati Kecamatan Gunungpati Semarang, (2) menguji ada tidaknya hubungan yang positif dan signifikan antara disiplin belajar dengan hasil belajar Mupel PJOK kelas V SD Negeri Gugus 
Larasati Kecamatan Gunungpati Semarang, (3) menguji ada tidaknya hubungan antara motivasi dan disiplin belajar secara bersamasama terhadap hasil belajar Mupel PJOK siswa kelas V SD Negeri Gugus Larasati Kecamatan Gunungpati Semarang.

\section{METODE PENELITIAN}

Penelitian ini merupakan penelitian kuantitatif dan termasuk jenis korelasi. Subjek dalam penelitian ini adalah siswa kelas V SDN Gugus Larasati Kecamatan Gunungpati Semarang meliputi SDN 1 Sumurejo, SDN 2 Sumurejo, SDN 1 Pakintelan, SDN 2 Pakintelan, dan SDN 3 Pakintelan. Teknik pengambilan sampel adalah sampling jenuh dengan sampel sebanyak 119 siswa. variabel dalam penelitian ini terdiri atas dua variabel bebas yaitu motivasi dan disiplin belajar dan satu variabel terikat yaitu hasil belajar Mupel PJOK.

Teknik pengumpulan data menggunakan observasi, wawancara, angket, dan dokumentasi. Angket dalam penelitian ini digunakan untuk mengetahui informasi tentang motivasi dan disiplin belajar yang dimiliki oleh masing-masing peserta didik, sedangkan hasil belajar Mupel PJOK diperoleh dari hasil Ulangan Harian Semester Genap tahun pelajaran 2019/2020. Sebelum instrumen penelitian digunakan, maka dilakukan uji coba. Selanjutnya peneliti menguji validitas dan realibilitas instrumen tersebut. Teknik analisis data yang digunakan pada penelitian ini adalah: (1) uji prasyarat meliputi uji normalitas, uji linieritas, dan uji multikolinieritas; (2) analisis statistik deskriptif; dan (3) analisis uji hipotesis menggunakan uji korelasi sederhana, uji korelasi ganda, uji signifikansi atau uji $\mathrm{F}$, dan uji koefisien determinasi.

\section{HASIL DAN PEMBAHASAN}

\section{Hasil Analisis Deskriptif}

Analisis deskriptif digunakan untuk mendeskripsikan data dari masing-masing variabel. Pada penelitian ini, deskripsi data yang dipaparkan meliputi deskripsi data variabel bebas yakni motivasi dan disiplin belajar serta deskripsi data variabel terikat yakni hasil belajar Mupel PJOK siswa kelas V SDN Gugus Larasati Kecamatan Gunungpati Semarang.

\section{Hasil Analisis Deskriptif Variabel Motivasi (X1)}

Jumlah pernyataan dalam angket motivasi terdiri atas 40 item. Hasil angket motivasi siswa yang terdapat di kelas V SDN Gugus Larasati Kecamatan Gunungpati Semarang dapat dilihat pada tabel berikut:
Tabel 1. Kategori Motivasi

\begin{tabular}{ccccc}
\hline $\begin{array}{c}\text { Interval } \\
\text { Skor }\end{array}$ & Frekuensi & $\begin{array}{c}\text { Persentase } \\
(\%)\end{array}$ & $\begin{array}{c}\text { Rata- } \\
\text { rata } \\
\text { Skor }\end{array}$ & Kategori \\
\hline $82-100$ & 106 & $89 \%$ & & \\
$63-81$ & 13 & $11 \%$ & & \\
$44-62$ & 0 & $0,00 \%$ & & \\
$25-43$ & 0 & $0,00 \%$ & & Sangat \\
& & & & Baik \\
\hline
\end{tabular}

Hasil Analisis Deskriptif Disiplin Belajar (X2)

Jumlah pernyataan dalam angket disiplin belajar terdiri atas 35 item. Hasil angket disiplin belajar siswa yang terdapat di kelas V SDN Gugus Larasati Kecamatan Gunungpati Semarang dapat dilihat pada tabel berikut:

Tabel 2. Kategori Disiplin Belajar

\begin{tabular}{ccccc}
\hline $\begin{array}{c}\text { Interval } \\
\text { Skor }\end{array}$ & Frekuensi & $\begin{array}{c}\text { Persentase } \\
(\%)\end{array}$ & $\begin{array}{c}\text { Rata- } \\
\text { rata } \\
\text { Skor }\end{array}$ & Kategori \\
\hline $82-100$ & 117 & $98,3 \%$ & & \\
$63-81$ & 2 & $1,68 \%$ & & \\
$44-62$ & 0 & $0,0 \%$ & & \\
& & & 91,956 & Sangat \\
$25-43$ & 0 & $0,0 \%$ & & Baik \\
\hline
\end{tabular}

\section{Hasil Analisis Deskriptif Hasil Belajar Mupel PJOK (Y)}

Hasil belajar mupel PJOK dalam penelitian ini diperoleh dari nilai PJOK siswa kelas V SDN Gugus Larasati Kecamatan Gunungpati Semarang pada Ulangan Harian 1 Semester Genap Tahun pelajaran 2019/2020.

Tabel 3. Kategori Hasil Belajar Mupel PJOK

\begin{tabular}{|c|c|c|c|c|}
\hline $\begin{array}{l}\text { Interval } \\
\text { Skor }\end{array}$ & $\begin{array}{l}\text { Frekuen } \\
\text { si }\end{array}$ & $\begin{array}{l}\text { Presentas } \\
\text { e }(\%)\end{array}$ & $\begin{array}{l}\text { Rata- } \\
\text { rata } \\
\text { Skor }\end{array}$ & $\begin{array}{l}\text { Kateg } \\
\text { ori }\end{array}$ \\
\hline \multicolumn{5}{|l|}{$90-100$} \\
\hline & 21 & 17,64 & & \\
\hline \multirow[t]{2}{*}{$80-89$} & 39 & 32,77 & & Cuku \\
\hline & & & 78,29 & $\mathrm{p}$ \\
\hline \multicolumn{5}{|l|}{$70-79$} \\
\hline & 38 & 31,93 & & \\
\hline \multicolumn{5}{|l|}{$<70$} \\
\hline & 21 & 17,64 & & \\
\hline Jumlah & 119 & $100 \%$ & & \\
\hline
\end{tabular}

\section{Hasil Uji Prasyarat Uji Normalitas}

Uji normalitas dilakukan untuk mengetahui data pada setiap variabel yang dianalisis berdistribusi normal (Sugiyono, 2017). Uji normalitas dalam penelitian ini mengacu pada model uji Kolgomorov-Smirnov. Berdasarkan hasil uji normalitas didapatkan harga signifikansi Asymp.Sig (2-tailed) sebesar 0,200 dimana harga signifikansi tersebut lebih besar dari 0,05. Maka dapat disimpulkan bahwa 
data berdistribusi normal. Dengan demikian, asumsi atau persyaratan normalitas sudah terpenuhi.

\section{Uji Linieritas}

Uji linieritas variabel motivasi dengan hasil belajar mupel PJOK diperoleh nilai signifikansi Deviation from Linearity 0,212 > 0,05 maka dapat disimpulkan bahwa antara motivasi dengan hasil belajar mupel PJOK terdapat hubungan yang linier. Sedangkan uji linieritas variabel disiplin belajar dengan hasil belajar mupel PJOK diperoleh nilai signifikansi Deviation from Linearity 0,704 > 0,05 maka dapat disimpulkan bahwa antara disiplin belajar dengan hasil belajar mupel PJOK terdapat hubungan yang linier.

\section{Uji Multikolinieritas}

Dari hasil uji multikolinieritas diketahui bahwa nilai Variance Inflation Factor (VIF) keua variabel bebas yaitu motivasi belajar dan disiplin belajar adalah 1,528 < 10 dan nilai Tolerance 0,654>0,10 maka dapat disimpulkan bahwa antarvariabel independen tidak terjadi multikolinieritas.

\section{Analisis Hipotesis}

Analisis hipotesis dalam penelitian ini menggunakan analisis korelasi sederhana, analisis korelasi ganda, uji signifikansi (uji F), dan uji koefisien determinasi.

\section{Hubungan Disiplin Belajar dengan Hasil Belajar Mupel PJOK}

Uji korelasi sederhana dalam penelitian ini menggunakan uji korelasi product moment. Hasil perhitungan dapat dilihat pada tabel berikut:

Tabel 4. Hasil Uji Korelasi Motivasi dengan Hasil Belajar

\begin{tabular}{lccc}
\hline $\begin{array}{l}\text { rhitun } \\
\text { g }\end{array}$ & $\begin{array}{c}\text { Taraf } \\
\text { Kesalahan }\end{array}$ & Sig. & $\begin{array}{c}\text { Uji } \\
\text { Determinasi }\end{array}$ \\
\hline 0,742 & 0,05 & 0,000 & $54,1 \%$ \\
\hline
\end{tabular}

Berdasarkan tabel 4 menunjukkan nilai rhitung lebih besar dari rtabel yaitu 0,742 > 0,195 , sehingga Ha1 diterima. Pada taraf signifikansi $5 \%$ didapatkan nilai signifikansi $0,000 \quad(0,000<0,05)$ sehingga korelasi dikatakan signifikan dan berlaku untuk populasi. Kontribusi motivasi dengan hasil belajar PJOK sebesar 55,1\%, artinya sumbangan hubungan motivasi belajar dengan hasil belajar PJOK sebesar 55,1\% dan sisanya $44,9 \%$ dipengaruhi oleh faktor lain yang tidak diteliti.

Pengujian hipotesis penelitian ini sejalan dengan penelitian yang pernah dilakukan oleh Penelitian oleh Zainal Abidin dan Sumarnur Ijrah (2018:21) dengan judul "Hubungan Motivasi Belajar Dengan Hasil Belajar Pada Siswa Kelas V SD Negeri Gugus IV
Kecamatan Banuhampu Kabupaten Agam". Hasil penelitian ini menunjukkan terdapat hubungan yang signifikan antara motivasi belajar dengan hasil belajar siswa.

Penelitian lain yang mendukung dilakukan oleh Brittany Kirkpatrick, Xiangli Gu, dkk (2016) dalam RQES: 2016 Convention Supplemen dengan judul "Children's Motivation in Physical Education, Physical Activity, and Pshycomotor Skills". Hasil dari penelitian ini adanya hubungan antara motivasi, tujuan penguasaan-pendekatan dan keterampilan psikomotorik anak-anak.

Selain itu penelitian yang dilakukan oleh Desi Eka Pratiwi dan Nindy Eka Prasetya (2019:40) dengan judul "Pengaruh Status Sosial Ekonomi dan Motivasi Belajar terhadap Prestasi Belajar Siswa Kelas V SDN Tambaksari I Surabaya". Hasil penelitian menunjukkan terdapat pengaruh positif antara status sosial ekonomi dan motivasi belajar secara bersamasama terhadap prestasi belajar siswa.

Berdasarkan perhitungan tersebut dapat disimpulkan bahwa terdapat hubungan yang positif dan signifikan antara motivasi dengan hasil belajar mupel PJOK siswa kelas V SDN Gugus Larasati Kecamatan Gunungpati Semarang. Artinya, semakin tinggi motivasi siswa maka akan semakin baik pula hasil belajar mupel PJOK yang diperoleh dan sebaliknya.

\section{Hubungan Disiplin Belajar dengan Hasil Belajar Mupel PJOK}

Uji korelasi sederhana dalam penelitian ini menggunakan uji korelasi product moment menunjukkan hasil uji korelasi sederhana antara variabel disiplin dan hasil belajar PJOK diperoleh nilai rhitung lebih besar dari rtabel yaitu $0,456>0,195$ dan nilai sig $0,000<0,05$, sehingga Ha2 diterima. Kontribusi disiplin belajar dengan hasil belajar PJOK sebesar 20,8\%, artinya sumbangan hubungan disiplin belajar dengan hasil belajar PJOK sebesar 20,8\% dan sisanya $79,2 \%$ dipengaruhi oleh faktor lain yang tidak diteliti.

Pengujian hipotesis penelitian ini sejalan dengan penelitian yang pernah dilakukan oleh Penelitian oleh Ryan Purbiyanto dan Ade Rustiana (2018:341) diambil dari Joyful Learning Journal dengan judul "Pengaruh Disiplin Belajar, Lingkungan Keluarga, dan Motivasi Belajar terhadap Hasil Belajar Siswa". Hasil penelitian ini menunjukkan terdapat hubungan antara disiplin belajar, lingkungan keluarga dan motivasi belajar terhadap hasil belajar siswa.

Selanjutnya, penelitian yang dilakukan oleh Philomena Mukami Njoroge dan Ann Nduku Nyabuto (2014) dengan judul "Discipline as a Factor in Academic Performance in Kenya". Penelitian ini menetapkan bahwa disiplin sangat penting untuk prestasi akademik di sekolah. Penelitian lain yang mendukung dilakukan oleh Pria Adi Saputra dan Putri Yanuarita (2017) dalam Joyful Learning Journal ISSN: 2252, dengan judul "Hubungan Fasilitas Belajar dan 
Motivasi Belajar Terhadap Hasil Belajar IPS Kelas V". Hasil penelitian menunjukkan adanya hubungan fasilitas belajar dan motivasi belajar terhadap hasil belajar siswa.

Berdasarkan perhitungan tersebut dapat disimpulkan bahwa terdapat hubungan yang positif dan signifikan antara disiplin belajar dengan hasil belajar mupel PJOK siswa kelas V SDN Gugus Larasati Kecamatan Gunungpati Semarang. Artinya, semakin tinggi disiplin belajar siswa maka akan semakin baik pula hasil belajar mupel PJOK yang diperoleh dan sebaliknya.

\section{Hubungan Motivasi dan Disiplin Belajar dengan Hasil Belajar Muapel PJOK}

Uji korelasi dalam penelitian ini menggunakan uji korelasi ganda. Hasil perhitungan dapat dilihat pada tabel berikut:

Tabel 6. Hasil Uji Korelasi Motivasi dan

Disiplin Belajar dengan Hasil Belajar

rhitun

g

Taraf
Kesalahan

Sig.

Uji

Determinasi

$$
0,743
$$

0,05

0,000

$55,1 \%$

Hasil analisis data berupa uji korelasi ganda antara variabel motivasi dan variabel disiplin belajar dengan variabel hasil belajar PJOK sebesar 0,743, angka tersebut merupakan angka positif atau searah. Nilai ftabel sebesar 3,09, sedangkan fhitung sebesar 71,304, hasil tersebut menunjukan bahwa fhitung $>$ ftabel yaitu 71,304 > 3,09, artinya korelasi ganda dinyatakan signifikan dan dapat diberlakukan untuk seluruh populasi. Perhitungan yang telah dilakukan oleh peneliti dapat disimpulkan bahwa terdapat hubungan yang signifikan antara motivasi dan disiplin belajar dengan hasil belajar Mupel PJOK siswa Kelas V SDN Gugus Larasati Kecamatan Gunungpati Semarang.

Pengujian hipotesis penelitian ini sejalan dengan penelitian yang pernah dilakukan oleh Azka Manazila dan Eko Purwanti (2017:69) diambil dari Joyful Learning Journal dengan judul "Hubungan Motivasi Belajar dan Disiplin Siswa dengan Hasil Belajar PKn Kelas V". Hasil penelitian ini menunjukkan bahwa terdapat hubungan yang positif, kuat dan signifikan antara motivasi belajar dan disiplin siswa secara bersama-sama dengan hasil belajar PKn kelas V SD Negeri Gugus Watubarut.

Penelitian lain yang mendukung dilakukan oleh Hendra Yusuf Prasetyo, Mujiyono pada tahun 2018 volume 7 nomor 2dalam Joyful Learning Journal dengan judul "Hubungan Motivasi Belajar Dan Sumber Belajar Dengan Hasil Belajar IPA Kelas V". Hasil penelitian menunjukkan adanya
Zahrotun Nasihah/ Joyful Learning Journal 9 (1) (2020) hubungan antara motivasi belajar dan sumber belajar dengan hasil belajar.

Selanjutnya penelitian yang dilakukan oleh Rizka Aprilia Dewi, Isa Ansori pada tahun 2018 volume 7 nomor 2 dalam Joyful Learning Journal dengan judul "Hubungan Kedisiplinan Dan Tanggung Jawab Terhadap Hasil Belajar PKn Kelas IV". Hasil Penelitian menunjukkan terdapat hubungan kedisiplinan dan tanggung jawab secara bersama-sama dengan hasil belajar PKn siswa.

Berdasarkan perhitungan tersebut dapat disimpulkan bahwa terdapat hubungan yang positif dan signfikan antara motivasi dan disiplin belajar bersama-sama dengan hasil belajar mupel PJOK siswa kelas V SDN Gugus Larasati Kecamatan Gunungpati Semarang. Motivasi dan disiplin belajar merupakan faktor yang memengaruhi hasil belajar mupel PJOK, dengan adanya motivasi dan disiplin belajar yang tinggi dari siswa maka akan meningkatkan hasil belajar mupel PJOK siswa begitu juga sebaliknya.

\section{SIMPULAN}

Berdasarkan hasil penelitian dan pembahasan, maka dapat disimpulkan bahwa terdapat hubungan yang positif dan signifikan antara motivasi dan disiplin belajar terhadap hasil belajar Mupel PJOK siswa kelas V SDN Gugus Larasati Kecamatan Gunungpati Semarang. Hal ini dibuktikan dengan data hasil penelitian bahwa rhitung > rtabel, yaitu 0,743 > 0,1801 pada taraf signifikansi $5 \%$, hubungan variabel motivasi belajar dan disiplin belajar dengan hasil belajar PJOK termasuk kategori kuat dan bernilai positif serta berkontribusi sebesar 57,5 \% dengan hasil belajar PJOK dan sisanya $55,1 \%$ dipengaruhi oleh faktor lain yang tidak diteliti dalam penelitian ini.

\section{UCAPAN TERIMA KASIH}

Ucapan terima kasih disampaikan kepada: Drs. Isa Ansori, M.Pd. sebagai dosen pembimbing pertama, Dra. Sri Susilaningsih, S.Pd., M.Pd., sebagai Mitra Bestari I, dan Drs. Sutaryono, M.Pd., sebagai Mitra Bestari II, yang telah memberikan bimbingan dan masukan dalam penyusunan manuskrip

\section{DAFTAR PUSTAKA}

Abidin, Zainal dan Sumarnur Ijrah.2018. Hubungan Motivasi Belajar Dengan Hasil Belajar Pada Siswa Kelas V SD

Negeri Gugus IV Kecamatan Banuhampu Kabupaten Agam. Jurnal Inovasi Pendidikan dan Pembelajaran Sekolah Dasar. Vol:2 No:2

B. Uno, Hamzah. 2019. Teori Motivasi dan Pengukurannya. Jakarta : PT Bumi Aksara 
Dewi, Aprilia \& Isa Ansori. 2018. Hubungan Kedisiplinan Dan Tanggung Jawab Terhadap Hasil Belajar PKn Kelas IV. dalam Joyful Learning Journal Vol:7 No:2

Hamalik, Oemar. 2015. Kurikulum dan Pembelajaran. Jakarta: Bumi Aksara

Kambuaya, Carlos. 2015. Pengaruh Motivasi, Minat, Kedisiplinan dan Adaptasi Diri Terhadap Prestasi Belajar Siswa Peserta Program Afirmasi Pendidikan Menengah Asal Papua dan Papua Barat. Bandung. Social Work Jurnal. Volume :5 No:2

Kirkpatrick, Brittany \& Xiangli Gu, dkk. 2016. Children's Motivation in Physical Education, Physical Activity, and Pshycomotor Skills. dalam RQES: 2016 Convention Supplemen.

Manazila, Azka dan Eko Purwanti. 2017. Hubungan Motivasi Belajar dan Disiplin Siswa dengan Hasil Belajar PKn Kelas V. dalam Joyful Learning Journal hal:69.

Njoroge, Philomena Mukami dkk. 2014. Discipline as a Factor in Academic Performance in Kenya. Journal of Educational and Social Research MCSER Publishing, Rome Italy. ISSN: 2239-978X/ISSN: 2240-0524. Vol:4 No:1

Prasetyo, Hendra Yusuf \& Mujiyono. 2018. Hubungan Motivasi Belajar Dan Sumber Belajar Dengan Hasil Belajar IPA Kelas V. dalam Joyful Learning Journal Vol:7 No:2.
Zahrotun Nasihah/ Joyful Learning Journal 9 (1) (2020)

Pratiwi, Desi Eka dan Nindy Eka Prasetya.2019. Pengaruh Status Sosial Ekonomi dan Motivasi Belajar terhadap Prestasi Belajar Siswa Kelas V SDN Tambaksari I Surabaya. Jurnal Pendidikan \& Pengajaran Guru Sekolah Dasar Vol 02, No 01

Purbiyanto, Ryan dan Ade Rustiana. 2018. Pengaruh Disiplin Belajar, Lingkungan Keluarga, dan Motivasi Belajar terhadap Hasil Belajar Siswa. dalam Joyful Learning Journal vol 7-no 2.

Saputra, Pria Adi dan Putri Yanuarita. 2017. Hubungan Fasilitas Belajar dan Motivasi Belajar Terhadap Hasil Belajar IPS Kelas V. dalam Joyful Learning Journal ISSN: 2252.

Slameto. 2013. Belajar dan Faktor-faktor Yang Memengaruhinya. Jakarta : Rineka Cipta.

Stanley, Ehiane, O..2015. Discipline and Academic Performance (A Study of Selected secondary Schools in Lagos, Nigeria). Dalam International Journal of Academic Research in Progressive Education and Development

Tu'u, Tulus. 2016. Peran Disiplin Pada Perilaku dan Prestasi Siswa. Jakarta: Gramedia Widiasarana Indonesia.

Ulfah, Khalida Rozana, Dkk.2011 Hubungan Motivasi dengan Hasil Belajar IPS. Jurnal Pendidikan. Vol:1. 